Eur. J. Clin. Chem. Clin. Biochem.

Vol. 32, 1994, pp. 3-4

(c) 1994 Walter de Gruyter \& Co. Berlin · New York

\title{
Increased Urinary Nitrate Excretion in Inflammatory Bowel Disease
}

\author{
By B. Melichar ${ }^{1}, R$. Karliček ${ }^{2}$ and M. Tichý ${ }^{1}$ \\ 1 Second Department of Internal Medicine, Faculty of Medicine \\ 2 Department of Analytical Chemistry, Faculty of Pharmacy \\ Charles University, Hradec Králové, Czech Republic
}

(Received July 19/September 22, 1993)

Summary: Urinary nitrate is known to be a measure of environmental exposure. Only recently an endogenous metabolic pathway resulting in nitrate synthesis was described. We have determined the concentration of nitrate expressed as nitrate/creatinine ratio in the urine of patients in whom a significant environmental nitrate load was presumed to be absent. A significant elevation of nitrates in patients with inflammatory bowel disease compared with patients with non-inflammatory disorders was observed $(0.173 \pm 0.155 \mathrm{vs} .0 .037 \pm 0.016 \mathrm{~mol} / \mathrm{mol}$ creatinine, $P<0.01)$. Increased nitrate excretion in the urine of patients with inflammatory bowel disease may reflect the endogenous nitrate synthesis induced by the immune activation.

\section{Introduction}

Urinary nitrate is often determined to assess environmental nitrate exposure (1). Only in the past few years, an endogenous metabolic pathway of nitrate production has been described (2). Nitrate represents a metabolite of nitric oxide, a molecule with diverse biologic activity, including an important role in immunologic defences (2). Recently, an increase in urinary nitrate excretion was reported in experimentally induced inflammation (3). Similar observations have been made in infectious diseases and ulcerative colitis $(4,5)$, but such studies are still rare due to the obvious difficulty in excluding interference by exogenous nitrate ingestion and further nitrate degradation by bacteria infecting the lower urinary tract.

\section{Materials and Methods}

We measured urine nitrate in 24 patients, 18 males and 6 females, mean age $37 \pm 17$ years (range 16-68), in whom the exogenous nitrate load was minimized for various reasons (total parenteral nutrition, fasting in preparation for diagnostic tests, refusal to receive food, or low-nitrate diet, i. e. diet without high nitrate content foods such as vegetables and cured meat, for at least 48 hours before the sample collection, when the influence of the previous nitrate exposure is known to abate (1)). No patients with urinary tract infection or on indwelling urinary catheter were included, because urinary nitrate was often undetectable in these subjects due to further nitrate metabolism by infecting bacteria. Most of the disorders were represented only by one patient with the notable exception of inflammatory bowel disease. Seven patients with inflammatory bowel disease (6 with Crohn's disease and one with ulcerative colitis) were evaluated, as total parenteral nutrition is frequently administered prior to operation in this disorder. Activity of the disease was estimated by assessment of clinical symptoms and certain laboratory quantities in a rating system applicable for both Crohn's disease and ulcerative colitis (6). Ten patients had a diagnosis not associated with inflammation ( 2 had obesity, 2 nonulcer dyspepsia and one each had Gilbert's syndrome, colon adenoma, irritable bowel syndrome, chronic fatigue syndrome, abdominal crisis in hypertriglyceridaemia and malnutrition resulting from refusal to receive foods). In patients with inflammatory bowel disease, as well as in the remaining 7 patients with gastric cancer, unclassified connective tissue disease, pneumatosis cystoides intestinalis, acute gastroenteritis, rheumatoid arthritis, vasculitis and sarcoidosis, some degree of inflammatory response is presumed to occur as a result of the disease. A sample of the first morning urine was collected and stored at $-20^{\circ} \mathrm{C}$ until analysis.

Nitrate was determined by flow injection analysis using the Griess reaction with $\mathrm{N}$-naphthylethylenediamine after reduction to nitrite by a cadmium column (7). Urine specimens diluted $1: 20(35 \mu \mathrm{l})$ were injected into the flow injection analyzer (FIA-20, JZD Plotiště, Hradec Králové, Czech Republic). Ammonium chloride/sodium tetraborate buffer was used as eluent. The absorbance was read at $545 \mathrm{~nm}$ wavelength and recorded. The nitrate concentration was determined from a calibration curve which was linear in the interval from 0.01 to $0.33 \mathrm{mmol} / \mathrm{l}$. Creatinine was measured by the Jaffé reaction with picric acid in alkaline solution on an automated analyzer (Hitachi 704) after dilution of the sample with distilled water $1: 50$. The results were expressed as nitrate/creatinine ratio ( $\mathrm{mol} / \mathrm{mol})$. Statistical evaluation was performed by the Mann-II'hitney $\mathrm{U}$ test. 
Tab. 1 Urinary nitrate in patients with infammatory bowcl disease.

\begin{tabular}{|c|c|c|c|c|c|}
\hline Pationt & Diagnosis & Activity & Medication & & $\begin{array}{l}\text { Urinary nitrate } \\
\text { (mol/mol creatinine) }\end{array}$ \\
\hline 1 & Crolnn's disease regional enteritis, colitis & Severe & $\begin{array}{l}\text { Sulfasalazine } \\
\text { Azathioprine }\end{array}$ & & 0.376 \\
\hline 2 & Crolin's disease colitis & Mild & Sulfasalazine & $\cdot 1$ & 0.056 \\
\hline 3 & Crohı's disease colitis & Moderate & $\begin{array}{l}\text { Sulfasalazine } \\
\text { Prednisone }\end{array}$ & & 0.088 \\
\hline 4 & Crohn's disease regional enteritis, colitis & Mild & Sulfasalazine & & 0.082 \\
\hline 5 & Crohn's disease regional enteritis, colitis & Severe & $\begin{array}{l}\text { Mesalamine } \\
\text { Azathioprine }\end{array}$ & & 0.182 \\
\hline 6 & Crohn's disease regional enteritis & Moderate & $\begin{array}{l}\text { Mesalamine } \\
\text { Prednisone }\end{array}$ & & 0.026 \\
\hline 7 & Ulcerative colitis & Moderate & Sulfasalazine & & 0.400 \\
\hline
\end{tabular}

\section{Results and Discussion}

The mean nitrate concentration in the whole group was $0.109 \pm 0.124 \mathrm{~mol} / \mathrm{mol}$ creatinine (range $0.017-0.400$ $\mathrm{mol} / \mathrm{mol}$ creatinine). The nitrate values in patients with inflammatory bowel disease were significantly higher than in subjects with disorders not associated with inflammatory response $(0.173 \pm 0.155$, range $0.026-$ $0.400 \mathrm{~mol} / \mathrm{mol} \mathrm{creatinine,} \mathrm{vs} 0.037 \pm 0.016$, range $0.017-0.077 \mathrm{~mol} / \mathrm{mol}$ creatinine, $\mathrm{P}<0.01$ ). The urinary nitrate excretion and some of clinical data of the patients with inflammatory bowel disease are shown in tab. 1. Elevated urinary nitrate in inflammatory bowel disease is of interest in the light of previous studies in patients with ulcerative colitis $(4,8)$ and may reflect increased production of nitric oxide by activated macrophages in the course of the disorder.

\section{References}

1. Packer, P. J., Leach, S. A., Duncan, S. N., Thompson, M. H. \& Hill, M. J. (1989) The effect of different sources of nitrate exposure on urinary nitrate recovery in humans and its relevance to the methods of estimating nitrate exposure in epidemiological studies. Carcinogenesis 10, 1989-1996.

2. Moncada, S., Palmer, R. M. J. \& Higgs, E. A. (1991) Nitric oxide: Physiology, pathophysiology, and pharmacology. Pharmacol. Rev. 43, 109-142.

3. Granger, D. L., Hibbs, J. B. \& Broadnax, L. M. (1991) Urinary nitrate excretion in relation to murine macrophage activation. $\mathrm{J}$. Immunol. 146, 1294-1302.

4. Wettig, K., Schulz, K. R., Scheibe, J., Diener, W., Fischer, G. \& Namaschk, A. (1991) Endogenous nitrate synthesis in selected infectious diseases and ulcerative colitis. Neoplasma 38, 337341.

5. Wettig, K., Schulz, K. R., Scheibe, J., Broschinski, L., Diener, W., Fischer, G. \& Namaschk, A. (1989) Nitrat- und Nitritgehalt
Among the subjects with other disorder associated with inflammatory response, individual patients with unclassified connective tissue disease, pneumatosis cystoides intestinalis and acute gastroenteritis also had urinary nitrate excretion outside the range observed in the group with non-inflammatory disorders $(0.201,0.294$ and $0.373 \mathrm{~mol} / \mathrm{mol}$ creatinine, respectively), while in others the urinary nitrate excretions were not conspicuous.

The data from the present preliminary study indicate that examining the first morning urine specimen may be a feasible alternative to a 24-hour urine collection in studying urinary nitrate excretion. Endogenous nitrate excretion appears to reach detectable values in inflammatory bowel disease, possibly reflecting the immunedependent nitric oxide production.

in Speichel, Urin, Blut und Liquor von Patienten einer Infektionsklinik. Wiener Klin. Wochenschr. 101, 386-388.

6. De Dombal, F. T., Burton, I. L., Clamp, S. E. \& Goligher, J. C. (1974) Short-term course and prognosis of Crohn's disease. Gut $15,435-443$.

7. Cortas, N. K. \& Wakid, N. W. (1990) Determination of inorganic nitrate in serum and urine by a kinetic cadmium-reduction. Clin. Chem. 36, 1440-1443.

8. Middleton, S. J., Shorthouse, M. \& Hunter, J. O. (1993) Increased nitric oxide synthesis in ulcerative colitis. Lancet 341 , $465-466$

Dr. Bohuslav Melichar

II. interni klinika

Lékařská fakulta Univerzity Karlovy

Pospišilova tř.

CZ-500 36 Hradec Králové

Czẹch Republic 